International

Medical Society

http://imedicalsociety.org

\title{
Childhood Depression in Family Narratives
}

\begin{abstract}
Matheus Felipe Aguiar Santos ${ }^{1}$, Alberto Olavo Advíncula Reis ${ }^{2}$, Marcial Moreno Moreira ${ }^{3}$, Carlos Augusto Carvalho de Vasconcelos ${ }^{4}$, Maria Engracia Loiola ${ }^{3}$, Nádia Nara Rolim Lima ${ }^{3}$, Uilna Natércia Soares Feitosa ${ }^{3}$, Ruan Neto Pereira Alves ${ }^{5}$, Regina Petrola Bastos Rocha ${ }^{6}$, Modesto Leite Rolim Neto1, 2, 3
\end{abstract}

\section{Abstract}

Background: The family narratives are true contextual cues in the representation of the experiences of illness of depressive child. The family members use healthcare services in an attempt to understand the disease so that describe the everyday practices in the living with the child.

Objective: This original article aims to present childhood depression with its various nuances and its many consequences in the family context.

Methods: The universe of this study involved 24 families in the age group ranging from 45 to 70 years who searched the care services at Children's Psychosocial Care Center (CAPSi). Through the records, a survey of the family members was performed, from case reports, in the course of medical and psychological consultations. This is a purposive sample, which was selected by approximation the inclusion criteria, a sample of 12 family members of both sexes. The attention focused on the use of narrative interview - which is recognized as a genre of sociolinguistic research - fully recorded.

Results: The family member has its convivial trajectory with the disease through a specific identity and enunciation with the child. The family narratives show up symbolic portraits to the rescue of the guiding elements of the depressive situation. The family narratives are shown as spaces of reinterpretation of pain and psychological distress. The disorder explained in the narratives of childhood depression inserted in understanding plays a crucial role in exposing the intensity of pain and psychological distress.
1 Faculty of Medicine, Federal University of Cariri, UFCA, Barbalha, Ceará, Brazil.

2 Postgraduate Program in Public Health, University of São Paulo, São Paulo, Brazil.

3 Postgraduate Program in Health Science. Faculty of Medicine of $A B C$, Santo André, São Paulo, Brazil.

4 Department of Neuropsychiatry, Federal University of Pernambuco, UFPE, Recife, Brazil.

5 Leao Sampaio Faculty, Course of Psychology, Juazeiro do Norte, Ceará, Brazil.

6 Regional University of Cariri - URCA, Crato, Ceará, Brazil.

\section{Contact information:}

\section{Modesto Leite Rolim Neto.}

Address: Faculty of Medicine. Federal University of Cariri- UFCA. 284, Divino Salvador Street, Barbalha, Ceará, Brazil.

Đmodestorolim@yahoo.com.br 
Conclusion: It is fundamental important in clinical care the psychiatric practice inserted into the historical and social context of the family members who have their own living narrative with the disease.

\section{Keywords}

Narrative; Childhood

depression; Family.

\section{Introduction}

Childhood depression is presented in post-modernity of multifaceted way, with its various nuances and its many consequences both within the family and in the society. [1, 2-11] The impact caused by the disease demonstrates that depression in childhood is, in addition to many other denominations, a public health phenomenon that is reaching alarming levels in populations at social risk. [12]

In this perspective, the family narratives may be positioned as true contextual cues in the representation of the illness experiences of depressive child. Thus, the interpretive process of a narrative gains its status of enunciation, particularly in what is being said in the interface of pain and psychological suffering. [13]

The enunciation of the disease, therefore, arises from the communicative movement between what is said and what is interdict of childhood depression in family narratives. [14] In this context, the said assumes own verbalized sentence, in other words, the statement of the complaint. The interdict, however, conveys what surrounds the suffering and mental pain that autosize in the situation experienced.

Thus, childhood depression is seen as the place that reveals the interdiction of the child what signals the existence of pain and the possibility of pronouncement of the facts and circumstances that present themselves as inconvenient. [15]

In this sense, the family use healthcare services in an attempt to understand the disease so that describe the everyday practices when living with the child, and gives a glimpse of true access codes to the disease and the reality of the facts. [16] Therefore it is necessary to consider that family narratives insist on the idea of understanding the truth of the communicative situation, reflected in the desire of listening. [17]

Thus, the feeling of fear propagated by the family is justified often by the poor economic situation coupled with the risk of their own internal conflict resulting from situations of social vulnerability. [18] In this perspective, the family due to the helplessness caused by the different dimensions of enunciation of the child's illness, interpret messages from living with the disease within the communication clinically intentioned. [19]

This article is based on the following question: how the family narratives in childhood depression can help in understanding the disease? This issue has gained great impact today with the establishment of interpretive way how the family tries to find clinical knowledge in pain and suffering contextualized in living with the child. Thus, this original article presents childhood depression with its various nuances and its many consequences in the family context. However, it is suggested that further studies on the importance of family narratives in childhood depression are conducted in order to establish a more solid relationship between family narratives and clinical interpretation in the depressive process.

\section{Methods}

The study population comprised 24 families in the age group ranging from 45 to 70 years old who searched the care services from the Children's Psychosocial Care Center (CAPSi). Consultations were motivated by circumstances surrounding suffering or mental pain linked to childhood depression. 
Figure 1: Mapping the sample space.

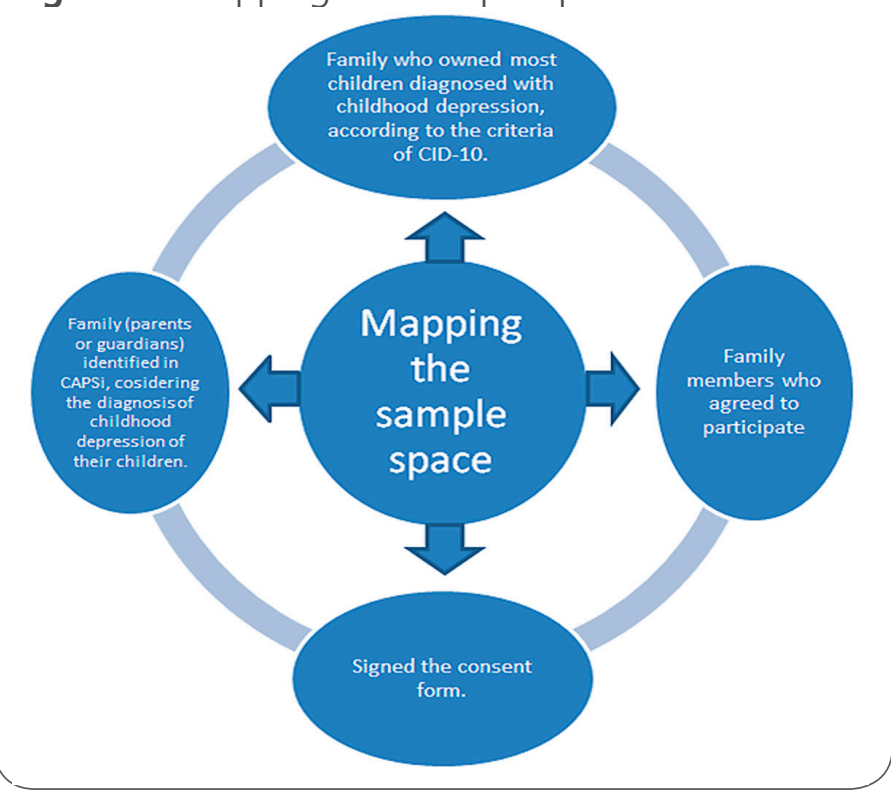

Through the records, a survey of family was performed, from case reports, in the course of medical and psychological consultations. Based on this information, the sample space was mapped.

\section{(Figure 1)}

From this perspective, it is a purposeful sample composed by cases rich in information for in-depth study, the standard sample mode. A sample by approximation the inclusion criteria of 12 family members of both sexes was selected. The priority, through sample, was given to subjects who had the information and experiences, considering a sufficient number for the recurrence of information, enabling the understanding of similarities and differences.

As data production method, our attention was focused on the use of narrative interview - which is recognized as a genre of sociolinguistic research - fully recorded. Open-ended questions are important in this genre and enable the respondent to report their experiences and opinions, and also a way to encourage respondents (called informants) to communicate the story about some important fact of their lives and the social context. In this perspective, the narrative is considered one of the modes of transmission of experienced situations.

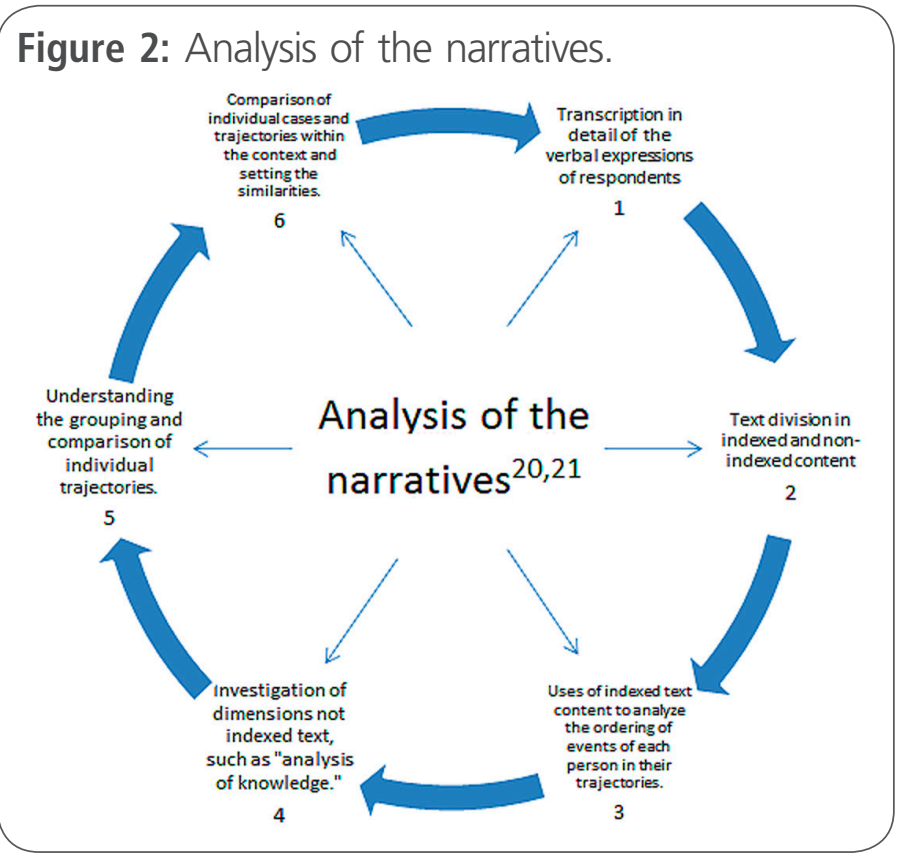

The narratives of the family were analyzed through six main steps. [20, 21] (Figure 2)

\section{Results}

The family narratives describe the perception of facts lived to living with childhood depression denoting through different utterances an essential understanding of the context of pain and psychological distress. Let's see what teaches about childhood depression a listen mother, aged 57: "It's anguish is cold [...] a bad thing that gradually kill the son of the people. It starts slowly, then increases, taking the life. It's weird, it is do not have a specific time to arrive." It is observed also that this mother in her narrative process reports the feeling and want to translate. Within the narrative is also interesting to note the content search for a truth concerning the experience of the disease. Foucault [22-24] points out that this search for truth has close association to what was going on here in the now unveiling with the situation. Thus, the family presents its convivial trajectory with the disease through a specific identity and enunciation with the child, which, for the family, is able to guide the situation of helplessness. 
In this sense, the interpretation of the interdict is surrounded in this context the "pain of being" of the family, established as the highest degree of psychological distress involved in communicative forms of the disease. The pain would be supported by the feeling of impotence to symptoms in living with disease. [25] "Pain of being" perceived as empty to exist; indescribable; immeasurable; nonphysical acute pain. [26]

Another family, 42 years-old, who works as a blacksmith, reveals: "Depression of my son is as caustic soda, corrodes everything inside." It can be said, from the terms used by the families during the act of narrating the "pain of being", that the family request is closely associated with committed listening of the narratives of living with the disease in primary care and the care from the health professional who must be able to understand the said and interdict elements during discourse. [27]

Thus, the family demonstrates how the course of the disease and its barriers are able to determine the forms of interpretation of utterances of pain and psychological distress. Let's see how a mother, 59 years old, reflects this attitude: "Depression of my son is like a flower that withered, even revenge, it is just dry branch asking for water, the silence is our greatest interpreter".

Therefore, the contextual cues of "pain of being" are identified in the family narratives, in other words, the silences that permeate the living itineraries with the disease. Thus, the real will of the informant is the will to be heard, understood, comforted and welcomed by a committed listening that takes into account the coexistence of trajectories and the actual feedback of the experienced situation. [28] Thus, the narratives trigger deficits in capture clinical diagnosis, in which are perceived only the said of utterances referring to what is prescribed by medication. [29]

Thus, the attempt to reframe the disease through the stories permeated by living with the child points out the urgent need to (re)interpret the disease and its manifestations in the informant perspective. As health professionals, it is necessary to facilitate the exchange of narratives in what contextualized to treatment. [30]

\section{Discussion}

The narratives of childhood depression are strongly committed to the influence of the disease in the family context and this perspective is externalized through contextual cues framed in pain and psychological distress inserted to the child. The family tries to narrate the confusing situation that characterizes the gaps/anxieties to events located to depression. Then the narrative is used as a stated tool that allows order the disorder of the reality of facts outlining a meaning for their coexistence with disease. [31]

The analysis of the troubled family situation promotes in the subjects themselves involved in child depression a sense of helplessness and despair, only because we did not understand the dynamics of lived facts and we do not know how to deal with this challenge in relation to the child. [32] The will to truth of the family is driven by the own analysis of the circumstances surrounding them, thereby leading the desire of families to be heard, understood and accepted in relation to doubts. [33] Thus, childhood depression is characterized as base element of the different issues and problems of reality of living with the disease. Thus, it is observed that what is intended to narrate, is to create opportunities to family, the projection of the various unresolved situations around the doctor-child-patient relationship. [34]

Thus, the family utterances carry with strong manifest content. They are shown true symbolic portraits to the rescue of the guiding elements of the depressive situation because these are the same utterances that reveal gradually the complex correlations between the different dimensions of living 
with the disease, whether biological, psychological and/or cultural. [35]

The narrative reports anguish, fear, anger and helplessness contextualizing the disease in the stratum of social reality. That's why the speech, with its variations of communicative forms, has, on the process of diagnosis and treatment of childhood depression, intense singular influence. Thus, the expository tool constitutes one of the ways for the real possibility of cure.

Therefore, the narrative content is not to ideology, but in action and in situations that action creates. [36] The oral language despite being used more often in daily life to establish and maintain social relationships constitutes also a communicative genre used to decipher and transfer information, [37] as well as the initial mechanism by which humans organize their experiences in episodes temporally significant. [37, 38] Thus, the family narrative - with its said and interdict - must be upheld and interpreted by a medical committed listening.

Thus, the family narratives work as true spaces of reinterpretation of pain and psychological distress. The spoken word with its said and interdict exposes the depth of everyday living. Thus, it appears as a particularly appropriate rich method for the study of understanding of the behavior of the real world. [28] The sense of coherence and meaning that are built by the subjects within themselves are reflected in their narratives of events of life. [39] In this perspective, committed listening tool constitutes a key starting point to address the informational difficulties for disease.

The disorder explained in the narratives inserted in understanding process of childhood depression plays a crucial role in exposing the intensity of pain and psychological distress. It is this disorder in portraying the depressive situation of the child in the social context that promotes in the family the extreme need of constant exercise of reflection on itself face to the collective consciousness with respect to childhood depression. Thus, the suffering in context family appears in the spaces of "pain of being" in the uncertainty of the clinical position; the inconstancy of living. [32]

Bochner [40] and Tierny [41] claim that it is through the narrative, that is, the act of offering voice to the unaided family member, which occurs the rescue to dignity and disrupts the systematic marginalization suffered by vulnerable social groups. It is the process to facilitate the creation of the proper sense in the context of disorganization of childhood depression through the act of narrating the pain and mental suffering that the subject, inserted in the family context of depressed, have the opportunity to grow psychologically. [42, 43]

\section{Conclusion}

The family narratives serve as an important predictor of what was happening with the "here" and "now" of the depressive child. Providing opportunities, in this way, that affective disorders interchange important contextual information in the interpretation of the lived situation, therefore, in what permeates the situational context, in relation to the moment of clinical interaction. In this sense, the participants (family members) in any face-to-face meeting in what pertains to children's spaces, use, at all times, contextualization cues that are related to both contextual information at the micro level (socio-interactive, personal) as the macro level (historical, institutional). [44]

It is known that, within the clinical context, there are more oriented psychiatric practice for the clinical treatment of more organismic nature and more psychoanalytic organizational practices, with a treatment that requires the doctor/patient relationship. $[44,45]$ So that it is truly important in clinical care psychiatric practice inserted into the historical and social context of the individual who has his narrative taking into account attempts to interpret the "pain of being." It is through this dynamic mes- 
Table 1. Sistematic Sequence of Action and Practical Implementation.

\begin{tabular}{|c|c|}
\hline Sistematic Sequence of Action & Practical Implementation \\
\hline Qualification of Personnel & Prepare the professional to treat and properly prevent the depressive child. \\
\hline $\begin{array}{l}\text { Promoting a approach of depressive } \\
\text { experience as an indicator of suicide }\end{array}$ & $\begin{array}{l}\text { Assign relevance to the words of family addressing the depressive phenomenon as an } \\
\text { indicator of suicidal process. }\end{array}$ \\
\hline $\begin{array}{l}\text { Informational chart apparatus with } \\
\text { emphasis on oral narratives }\end{array}$ & $\begin{array}{l}\text { Cartography therefore becomes a mapping of a phenomenon, taking into account its } \\
\text { range, movement and evolution. }\end{array}$ \\
\hline $\begin{array}{l}\text { Social framework of collective } \\
\text { production }\end{array}$ & $\begin{array}{l}\text { The social framework of collective production has cast off the concern with social } \\
\text { exclusion caused by pain and peculiar psychological distress to the disease. In this } \\
\text { sense it is needed to establish a transdisciplinary. }\end{array}$ \\
\hline $\begin{array}{l}\text { Applicability of methodological } \\
\text { intervention of intervention }\end{array}$ & $\begin{array}{l}\text { It is possible to set a standard model of disease coping with a focus on the family } \\
\text { thinks, says and interdict in his speech, to reveal the feelings of pain and mental } \\
\text { suffering of the depressive phenomenon. }\end{array}$ \\
\hline $\begin{array}{l}\text { Recognition of own utterances of } \\
\text { the family culture }\end{array}$ & $\begin{array}{l}\text { The method to be applied should value and boost the professional interpretation, } \\
\text { offering a hand to family members, to fill in the gaps of the disease in their everyday } \\
\text { translation. }\end{array}$ \\
\hline $\begin{array}{l}\text { Introduction of public health } \\
\text { policies to rethink the care }\end{array}$ & $\begin{array}{l}\text { The introduction of public health policies may provide the rethinking of care, } \\
\text { intervention and treatment of disease in CAPSi. The primary purpose of these policies } \\
\text { is a unique opportunity to restructure the professional body at the expense of the } \\
\text { needs identified in the course of childhood depression. }\end{array}$ \\
\hline $\begin{array}{l}\text { Partnerships with various institutes } \\
\text { of the social area and health to } \\
\text { collaborate in the healing process of } \\
\text { the issues of depression }\end{array}$ & $\begin{array}{l}\text { Projects, partnerships and NGO proposals also suggest support in this process, as } \\
\text { they require incision and social policy to the community, and the support dispensed } \\
\text { by society to these institutions, which can contribute massively in the socialization } \\
\text { process of childhood depression. }\end{array}$ \\
\hline
\end{tabular}

sage of contextualization stated by the respondent that the interdict lines subjectivate the mechanism of pain and suffering, being urgent, therefore, the need to foster a culture of committed listening in medical support in primary care. [44, 46]

Therefore the resetting of function and incorporation of the new concepts in the enunciation of the disease outlines the importance of the said and interdict of childhood depression in family narratives, allowing inserted subjects in the context of disease a clearer and more humane interpretation of the variation of communicative forms having the interdict as the main socio-cultural tool to contextualize the child depression phenomenon. More broadly, the introduction of public health policies can provide the rethinking of care, intervention and treatment of disease in CAPSi.

Thus, at the level of suggestion for intervention and treatment of depression, the practice to be performed consists in a systematic sequence of actions, aiming to review and rethink how to address childhood depression. For this, the elements were mapped those link the essentiality of this proposal. (Table 1)

\section{References}

1. Avanci J, Assis S, Oliveira R, Pires T. Childhood depression. Exploring the association between family violence and other psychosocial factors in low-income Brazilian schoolchildren. Child Adolesc Psychiatry Ment Health. 2012; 6(1): 26.

2. Reynolds MH, Wallace J, Hill TF, Weist MD, Nabors NA: The relationship between gender, depression, and self-esteem in children who have witnessed domestic violence. Child Abuse Negl 2001, 25: 1201-1206.

3. Kennedy AC, Bybee D, Sullivan CM, Greeson M: The impact of family and community violence on children's depression trajectories: Examining the interactions of violence exposure, family social support, and gender. J Fam Psychol 2010, 24(2): 197-207. 
4. Bagner DM, Pettit JW, Lewinsohn PM, Seeley JR: Effect of Maternal Depression on Child Behavior: A Sensitive Period? J Am Acad Child Adolesc Psychiatry 2010, 49(7): 699-707.

5. Hale WW, Valk IVD, Engels R, Meeus W: Does perceived parental rejection make adolescents sad and mad? The association of perceived parental rejection with adolescent depression and aggression. J Adolesc Health 2005, 36(6): 466-474.

6. Gray LB, Weller RA, Fristad M, Weller EB: Depression in children and adolescents two months after the death of a parent. J Affect Disord 2011, 135(1-3): 277-283.

7. Hennessy MB, Deak T, Schiml-Webb PA: Early attachment-figure separation and increased risk for later depression: Potential mediation by proinflammatory processes. Neurosci Biobehav Rev 2010, 34(6): 782-790.

8. Burnette JL, Davis DE, Green JD, Worthing EL Jr, Bradfield E: Insecure attachment and depressive symptoms: The mediating role of rumination, empathy, and forgiveness. Personality and Individual Differences 2009, 46(3): 276-280.

9. Goodyer IM: Life events: their nature and effects. In The depressed child and adolescent. Edited by Goodyer I. United Kingdom: Cambridge University Press; 2001: 204-232.

10. László M, Lopez-Duran NL, Kovacs M, George CJ, Baji I, Kapornai K, Kiss E: Vetró: Stressful life events in a clinical sample of depressed children in Hungary. J Affect Disord 2009, 115(12): $207-214$.

11. Birmaher B, et al: Childhood and adolescent depression: $A$ review of the past 10 years, Part I. J Am Acad Child Adolesc Psychiatry 1996, 35: 1427-1439.

12. Lewis KJ, Mars B, Lewis G, et al. Do parents know best? Parentreported vs child-reported depression symptoms as predictors of future child mood disorder in a high-risk sample. J Affect Disord. 2012; 141(2-3): 233-236.

13. Ekanayake S, Ahmad F, McKenzie K. Qualitative cross-sectional study of the perceived causes of depression in South Asian origin women in Toronto BMJ Open 2012; 2: e000641.

14. Neto MLR, Reis AOA ; Abreu LC; Almeida, JC et al. Depression in children and adolescents: family narratives in Brazilian primary attention. HealthMed; 2012, 6 (9): 2950.

15. Forbes EE, Stepp SD, Dahl RE, Ryan ND, Whalen D, Axelson DA, Birmaher B, Silk JS. Real-world affect and social context as predictors of treatment response in child and adolescent depression and anxiety: an ecological momentary assessment study. J Child Adolesc Psychopharmacol. 2012, 22(1): 37-47.

16. Martin KJ. "Oh, I have a story": narrative as a teacher's classroom model. Teaching and Teacher Education, 2000, 16: 349-363.

17. Suárez-Ortega M. Performance, Reflexivity, and Learning Through Biographical-Narrative Research. Qualitative Inquiry March 2013, 19 (3): 189-200
18. Ochi M, Fujiwara T, Mizuki R, Kawakami N; World Mental Health Japan Survey Group. Association of socioeconomic status in childhood with major depression and generalized anxiety disorder: results from the World Mental Health Japan survey 2002-2006. BMC Public Health. 2014, 14, 14: 359

19. Kelly $T$, Howie L. Working with stories in nursing research: procedures used in narrative analysis. Int J Ment Health Nurs. 2007, 16(2): 136-44.

20. Schutze, F. Die technik des narrativen interviews in interaktionsfeldstudien - dargestelli an Einem projekt zur erforschung von kommunalen machtstrukturen. Manuscript of Bielefeld, Departament of sociology 1977. [in press]

21. Schutze, F. Narrative repraesentation kollektiver schisksalsbetroffenheit. In: Laemmert, E. Erzaehlforschung. Stuttgart: J.B. Mentzler, 1983.p. 568-90.

22. Foucault, M. L'ordre du discours. Paris: Gallimard, 1971

23. Foucault, M. A arqueologia do saber. Rio de Janeiro: Forense, 1986.

24. Foucault, M. Microfísica do poder. Rio de Janeiro: Graal, 1992.

25. De Haene L, Grietens H, Verschueren K. Holding harm: narrative methods in mental health research on refugee trauma. Qual Health Res. 2010, 20(12): 1664-76.

26. Peres, U.T. Depressão e melancolia. Rio de Janeiro: Jorge Zahar Editores, 2003

27. Kirkpatrick H. A narrative framework for understanding experiences of people with severe mental illnesses. Arch Psychiatr Nurs. 2008, 22(2): 61-8.

28. Callahan C, Elliott CS. Listening: A narrative approach to everyday understandings and behavior. Journal of Economic Psychology, 1996, 17(1): 79-114

29. Winterbottom A, Bekker HL, Conner M, Mooney A. Does narrative information bias individual's decision making? A systematic review. Soc Sci Med. 2008, 67(12): 2079-88.

30. Sools A. Narrative health research: exploring big and small stories as analytical tools. Health (London). 2013, 17(1): 93-110.

31. Herrmann AF. How Did We Get This Far Apart? Disengagement, Relational Dialectics, and Narrative Control. Qualitative Inquiry October 2007, 13(7): 989-1007

32. Neto MLR; Reis AOA; Braga IB; Macêdo CHF. Chaos and order: disrupted lives by depression. HealthMed; 2011, 1(5): 1878.

33. Donald E. Polkinghorne. Validity Issues in Narrative Research. Qualitative Inquiry; 2007, 13(4): 471-486

34. Weeks, M., Cairney, J., Wild, T.C., Naicker, K., Colman, I. Earlylife predictors of internalizing symptom trajectories in Canadian children. Australian and New Zealand Journal of Psychiatry. 2014; 48 (7): 672-680

35. Neto MLR, Silva TN, Filho JKMA, Carvalho RS et al. Childhood depression and psychocognitive development: description of causality relationships. Journal of Human Growth and Development. 2011; 21(3): 894-898.

36. Havelock, E. A. The muse learns to write. New Haven, NY: Yale University Press. 1986 
37. Özyildirim, I. Narrative analysis: An analysis of oral and written strategies in personal experience narratives. Journal of Pragmatics. 2009, 41(6): 1209-1222.

38. Richardson, Laurel, 1990. Narrative and sociology. Journal of Contemporary Ethnography, 1990, 19: 116-135.

39. Ville I, Khlat M. Meaning and coherence of self and health: an approach based on narratives of life events. Soc Sci Med. 2007, 64(4): 1001-14.

40. Bochner, A. P. Narrative's virtues. Qualitative Inquiry, 2001, 7: 131-157.

41. Tierny, W. G. Undaunted courage. Life history and the postmodern challenge. In N. K. Denzin \& Y. S. Lincoln (Eds.), Handbook of qualitative research. Thousand Oaks, CA: Sage, 2000, p. 537-553.

42. Chase, S. E. Narrative inquiry: Multiple lenses, approaches, voices. In N. K. Denzin \& Y. S. Lincoln (Eds.), The Sage handbook of qualitative research. Thousand Oaks, CA: Sage, 2005, p. 651-679.

43. Frank, A. W. (2000). Illness and autobiographical work: Dialogue as narrative destabilization. Qualitative Sociology, 2000, 23: 135-156.

44. Ribeiro BT, Pereira MGD. A noção de contexto na análise do discurso. VEREDAS. Rev. Est. Ling., 2002, 6(2): 49-67.

45. Costa lima, C. e Lopes Dantas, M. T. (Eds.). Narrativa, Identidade e Clínica. Rio de Janeiro: IPUB/CUCA, 2001.

46. Bateson, G. Uma Teoria sobre Brincadeira e Fantasia. In: B.T. Ribeiro \& P. Garcez (Eds.). Sociolinguística Interacional. São Paulo: Loyola. 2002. p. 85-105

Publish in International Archives of Medicine

International Archives of Medicine is an open access journal publishing articles encompassing all aspects of medical science and clinical practice. IAM is considered a megajournal with independent sections on all areas of medicine. IAM is a really international journal with authors and board members from all around the world. The journal is widely indexed and classified Q1 in category Medicine. 